\title{
Sensory Analysis of Sweet Musts in Pedro Ximenez cv. Grapes Dried using Different Methods
}

\author{
M.P. Serratosa, A. Marquez, A. Lopez-Toledano, J. Merida* \\ Department of Agricultural Chemistry, Faculty of Sciences, University of Cordoba, Edificio Marie Curie, Campus de Rabanales, \\ E-14014 Cordoba, Spain
}

Submitted for publication: May 2011

Accepted for publication: October 2011

Key words: Sweet wines, Pedro Ximenez, sensory analysis

\begin{abstract}
The sensory properties of musts from Pedro Ximenez grapes chamber-dried at 40 or $50^{\circ} \mathrm{C}$, with or without a dipping treatment, are compared to musts from grapes subjected to the traditional sun-drying method used in the production of sweet wines. The chamber-dried procedure, specifically at $50^{\circ} \mathrm{C}$, decreased the drying time, improved the health status of the grapes relative to the growth of fungi that produce toxins and yielded must with a very similar color to that of sun-dried grapes. Sensory evaluation has shown that must from grapes dried at $50^{\circ} \mathrm{C}$, after treatment with an alkaline emulsion of ethyl oleate, is unacceptable due to the light color. The musts receiving the highest scores for color, aroma and flavor were from untreated grapes dried at $50^{\circ} \mathrm{C}$ or potassium carbonate-treated grapes dried at the same temperature. However, the treatment did not significantly accelerate drying.
\end{abstract}

\section{INTRODUCTION}

Pedro Ximenez grapes, typically grown in southern Spain, are used in the production of sweet white wines by using special grape drying techniques. The grapes are sun-dried to reduce sugar levels to approximately $450 \mathrm{~g} / \mathrm{L}$. Drying of the grapes produces a dark-colored, intensely sweet must with a strong raisin flavour. The intensified brown color of the must is the result of the combined action of polyphenol oxidases (PPO) and the Maillard reaction (Ramshaw \& Hardy, 1969; Grncarevic \& Hawker, 1971). Polyphenol oxidases act preferentially on esters of hydroxycinnamic acids (Cheynier et al., 1989), but their activity is inhibited by the drying process and the increased sugar content of the grapes (Radler, 1964). The Maillard reaction is especially favorable above $50^{\circ} \mathrm{C}$ and at pH 4-7 (Morales \& Jimenez-Perez, 2001). This reaction produces "melanoidins", which are highmolecular weight compounds with a poorly known structure that contribute to wine browning and chromatic parameters. In addition, these compounds promote antioxidant activity (Lingnert \& Hall, 1986).

Grapes are dried in various ways, with exposure to the sun being the most common method. The traditional sundrying method requires specific temperatures and humidity, preferably a hot and dry climate. In recent years a number of alternative methods, including drying in the shade and mechanical drying were developed (Pangavhane et al., 2002). Mechanical drying methods are safer, faster, more easily controlled and unaffected by the climatic conditions.
The method may also be combined with sun-drying for specific advantages (Pangavhane et al., 2002). Mechanical drying methods can also be combined with chemical grape treatments to facilitate and expedite the drying time (Raouzeos \& Saravacos, 1986; Riva et al., 1986; Saravaco et al., 1988; Mahmutoglu et al., 1996; Karathanos \& Belessiotis, 1997; Pangavhane et al., 1999; Doymaz \& Pala, 2002; Azzouz et al., 2002). The use of an oil emulsion or diluted alkaline solution is especially prevalent to accelerate drying, as it lowers the resistance to moisture transfer in the grapes (Saravacos et al., 1986). Phenol compound and colour changes of Pedro Ximenez grapes during traditional sun-drying in southern Spain have been studied (Serratosa et al., 2008a), along with the effect of alternative techniques involving chamber-drying under controlled temperature and moisture conditions (Serratosa et al., 2008b), with the latter being more expeditious than the traditional sun-drying procedure. However, conclusive assessment of the suitability of these alternative procedures requires sensory evaluation of the final product.

The primary aim of this study was to assess how consumers perceive musts from grapes subjected to alternative drying methods. Sensory evaluation was performed on Pedro Ximenez must prepared from sun-dried grapes and compared with musts prepared from pretreated and untreated grapes dried in a chamber at controlled temperature and moisture. 


\section{MATERIALS AND METHODS}

\section{Grapes}

Experiments were conducted with Pedro Ximenez grapes grown in the Montilla-Moriles region (Cordoba, Spain).

\section{Sun-drying}

Samples were obtained from grapes extended and exposed to the sun on 10 drying mats of approximately 20 meters each. The grapes were randomly collected in triplicate $8 \mathrm{~kg}$ batches from the start (day 0) to completion (day 7) of the drying process. The sugar content of the grapes changed from $204.8 \mathrm{~g} / \mathrm{L}$ on the first day to $495.4 \mathrm{~g} / \mathrm{L}$ on the final day (168 h, sample R).

\section{Chamber-drying}

Each assessment was performed with $6 \mathrm{~kg}$ of grapes with a reduced sugar concentration of $210.6 \mathrm{~g} / \mathrm{L}$ that were uniformly spread at a density of $14 \mathrm{~kg} / \mathrm{m}^{2}$ on trays, and placed in a drying chamber at a constant temperature and humidity. The experiment involved triplicate runs of the following processes:

- Drying untreated grapes at $40^{\circ} \mathrm{C}$ for $120 \mathrm{~h}$ to a reduced sugar concentration of $490.0 \mathrm{~g} / \mathrm{L}$ (sample 40-0).

- Drying untreated grapes at $50^{\circ} \mathrm{C}$ for $70 \mathrm{~h}$ to a reduced sugar concentration of $495.4 \mathrm{~g} / \mathrm{L}$ (sample 50-0).

- Drying at $50^{\circ} \mathrm{C}$ of grapes previously dipped in an alkaline emulsion of olive oil $\left(7 \% \mathrm{~K}_{2} \mathrm{CO}_{3}+0.4 \%\right.$ commercial oil) at room temperature for $1 \mathrm{~min}$. The treated grapes were dried for $55 \mathrm{~h}$ to obtain a reduced sugar concentration of $503.4 \mathrm{~g} / \mathrm{L}$ (sample 50-1).

- Drying at $50^{\circ} \mathrm{C}$ of grapes previously dipped in an alkaline emulsion of ethyl oleate $\left(2.5 \% \mathrm{~K}_{2} \mathrm{CO}_{3}\right.$ $+2 \%$ ethyl oleate) at room temperature for 10 seconds, the treated grapes being dried for $48 \mathrm{~h}$ to obtain a reduced sugar concentration of $462.2 \mathrm{~g} / \mathrm{L}$ (sample 50-2).

\section{Must preparation}

Grapes were crushed and then pressed in a vertical press similar to the industrial models at a maximum pressure of 300 bar for each one of three samples. The musts were clarified by centrifugation at $268.3 \mathrm{xg}$.

\section{Spectrophotometric and CIELAB measurements}

Browning in the musts was assessed via light absorbance at $420 \mathrm{~nm}$. The CIELAB parameters L* (lightness), $\mathrm{h}_{\mathrm{ab}}$ (hue) and $\mathrm{C}^{*}{ }_{\mathrm{ab}}$ (chroma) were determined in accordance with the recommendations of the International Commission on Illumination (CIE, 2004), using the D65 illuminant and the $10^{\circ}$ standard observer. Measurements were processed with Colvin v. 1.00.04 software from Perkin Elmer (California, USA).

All spectrophotometric measurements were done on a Perkin Elmer Lambda 25 instrument, using quartz cells of $10 \mathrm{~mm}$ path length, after filtration of the musts through Millipore HA paper with $0.45 \mu \mathrm{m}$ pore size.

\section{Reagents}

Phenolic acids and catechins were purchased from SigmaAldrich Chemical Co. (Madrid, Spain). Flavonols were obtained from Extrasynthese (Genay, France). Methanol, formic acid, hydrochloric acid, acetonitrile and purified water were purchased from Merck (Madrid, Spain).

\section{Extraction of phenolic compounds}

Phenolic compounds were extracted by using Sep-Pak C18 cartridges packed with $900 \mathrm{mg}$ of filling (Long Body SepPak Plus, Waters Associates, Milford, MA) which were previously conditioned by passing $8 \mathrm{~mL}$ of methanol and 8 $\mathrm{mL}$ of water at pH 7 (Jaworski \& Lee, 1987). A volume of $25 \mathrm{~mL}$ of must, adjusted to $\mathrm{pH} 7$ with $\mathrm{NaOH}$, was passed through the cartridge, followed by elution with $5 \mathrm{~mL}$ of water at $\mathrm{pH}$ 7. The initial fraction was collected for analysis of phenolic acids and esters of hydroxycinnamic acids. After that, the cartridge was conditioned with $2 \mathrm{~mL}$ of water at $\mathrm{pH}$ 2 and the flavan-3-ol fraction collected by elution with $8 \mathrm{~mL}$ of $16 \%$ acetonitrile $\left(\mathrm{CH}_{3} \mathrm{CN}\right)$ in water at $\mathrm{pH} 2$ (Oszmianski et al., 1988). The flavonol fraction was eluted with $10 \mathrm{~mL}$ of methanol. The three fractions were concentrated and were passed through a filter with $0.45 \mu \mathrm{m}$ pore size prior to analysis on an HPLC Spectra-Physics P4000 instrument.

\section{Identification and analysis by HPLC}

Identification of the phenolic compounds was by comparing the retention times of the standards with UV spectra obtained with a HPLC Dyode Array (Spectra-Physics UV6000LP) and UV absorbance ratios calculated after co-injection of samples and standards. Analyses were performed on a LiChrospher $100 \mathrm{RP}-18$ column $(250 \mathrm{~mm} \times 4.6 \mathrm{~mm}, 5 \mu \mathrm{m}$ particle size), using $2 \%$ aqueous formic acid and a combination of 80:18:2 acetonitrile/water/formic acid as mobile phase, at a flow rate of $1 \mathrm{~mL} / \mathrm{min}$ (Serratosa et al., 2008a). Phenolic acids and flavan-3-ol derivatives were detected at $280 \mathrm{~nm}$, hydroxycinnamic esters at $315 \mathrm{~nm}$ and flavonols at $360 \mathrm{~nm}$.

The elution phases were as follows: gradient elution from 5 to $10 \% \mathrm{CH}_{3} \mathrm{CN}$ in $25 \mathrm{~min}$; gradient to $20 \% \mathrm{CH}_{3} \mathrm{CN}$ in $10 \mathrm{~min}$; gradient to $30 \% \mathrm{CH}_{3} \mathrm{CN}$ in $10 \mathrm{~min}$; gradient to $100 \%$ $\mathrm{CH}_{3} \mathrm{CN}$ in $15 \mathrm{~min}$ and isocratic elution for $10 \mathrm{~min}$ (Serratosa et al., 2008a).

\section{Quantitation of phenolic compounds in must}

The standards used to determine phenolic compounds were supplied in $95-99 \%$ purity by Sigma-Aldrich Chemical Co. (Madrid, Spain) and Extrasynthese (Genay, France). The results for each compound were interpolated in a calibration curve obtained from the corresponding standards; by exception, caftaric, cutaric and feftaric acid were quantified as caffeic, p-coumaric and ferulic acid, respectively, and procyanidins were quantified as $(+)$-catechin.

\section{Sensory analysis}

The musts were assessed for color, aroma and flavor acceptability by 15 tasters in two panels in accordance with ISO 8586-1-1993. The tasting room was kept at $20^{\circ} \mathrm{C}$ and musts served in tasting glasses certified in accordance with UNE 87-022-92 - the Spanish equivalent of ISO 3591-1977. The glasses were coded with tree-digit blinding codes and 
covered to prevent sensory losses in the musts. The tasters were instructed in advance about their task and the rules to be followed, and were given a scoring sheet.

Evaluation of the quality of the musts was made using the method according to UNE 87-020-93 (ISO 4121:1987), with options of desirable (3), acceptable (2) and undesirable (1). Reference samples evaluated as undesirable were rejected. Two different assessment test panels were used:

- First Panel: Evaluation of aroma and flavor.

- Second Panel: Evaluation of color.

\section{RESULTS AND DISCUSSION}

The drying process causes substantial water loss, and hence results in a gradual increase in concentration of all grape components (Serratosa et al., 2008b). Since the consumption of reducing sugars by caramelization, especially the Maillard reaction, was very low, the increase in sugar concentration can be used to estimate the concentration effect of the drying process.

The browning index of the different musts, measured via their increased absorbance at $420 \mathrm{~nm}$, is shown in Fig. 1. Very little browning occurred in must prepared from grapes dried at $40^{\circ} \mathrm{C}$ in the chamber $(0.097 \mathrm{au})$. This may be to the weak synthesis of browning compounds at this temperature. The index was $0.704 \mathrm{au}$ in the reference must (R), whereas those of the three musts from dipped and un-dipped grapes dried at $50^{\circ} \mathrm{C}$ increased by more than one unit. These differences in the increase in absorbance at $420 \mathrm{~nm}$ (A420) could be ascribed to the enzymatic and non-enzymatic browning reactions during the drying process. Enzymatic browning occurs through the action of polyphenol oxidases on phenolic compounds. The Maillard reaction is especially favourable above $50^{\circ} \mathrm{C}$ (Morales \& Jimenez-Perez, 2001). The traditional sun-drying process involves large temperature changes from levels above $50^{\circ} \mathrm{C}$ on the surface of grape skins during mid-day, favoring the Maillard reaction, to much lower temperatures at night. A constant temperature of $40^{\circ} \mathrm{C}$ in the drying-chamber reduced browning, whereas a temperature at $50^{\circ} \mathrm{C}$ induced the Maillard reaction to an extent even greater than in the traditional sun-drying process, which is desirable in the elaboration of these type of wines.

The variation of lightness $\left(\mathrm{L}^{*}\right)$ and the angular coordinates in the CIELAB space $\left(\mathrm{h}_{\mathrm{ab}}\right.$ and $\left.\mathrm{C}^{*}{ }_{\mathrm{ab}}\right)$ for the musts is shown in Fig. 2. The CIELAB coordinates differed for the musts from sun-dried and chamber-dried grapes at $50^{\circ} \mathrm{C}$, with the latter exhibiting a decrease in lightness (i.e. darkening) and hue (reddening). However, lightness in the must from grapes dried at $40^{\circ} \mathrm{C}$ in the chamber slightly increased; in fact, the final must was lighter and slightly yellowish due to the effect of its increased hue relative to the starting must. Chroma increased in all musts, which indicated that grapedrying increased must color, most evident in the must from grapes dried at $50^{\circ} \mathrm{C}$ in the chamber, followed by must from sun-dried grapes and lastly the must from grapes dried at $40^{\circ} \mathrm{C}$ in the chamber.

Variation in the concentrations of phenolic acids, hydroxycinnamic esters, flavans, procyanidins and flavonols during the different drying processes is shown in Fig. 3. In the absence of reactions in the grape, grape-drying should increase the contents in phenolic compounds of the must through the above-described concentration effect of water evaporation from the grapes. However, some of these compounds can be consumed in non-enzymatic browning, autoxidation and especially enzymatic oxidation reactions

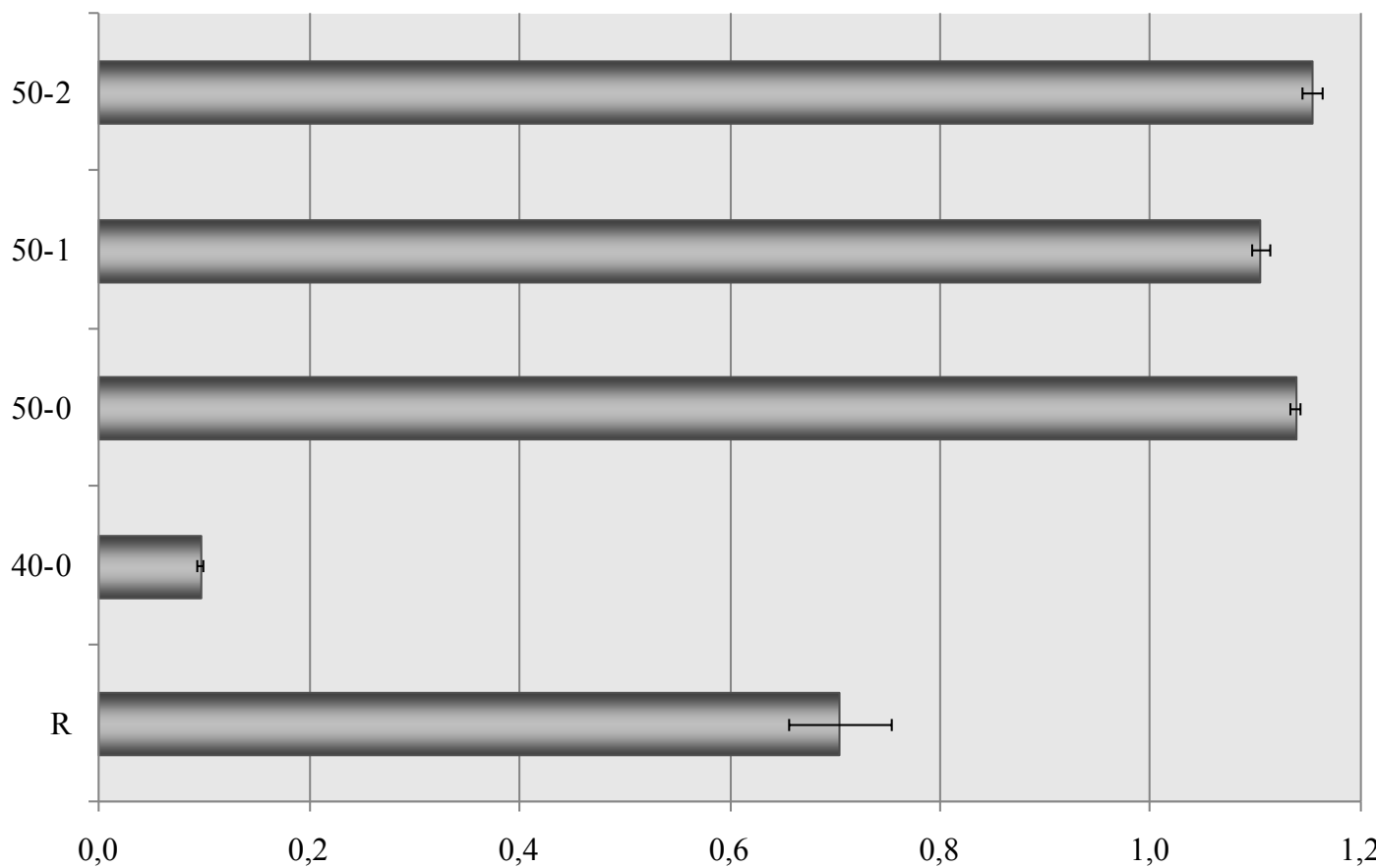

Browning index (a.u.)

FIGURE 1

Browning index measured as an increase of light absorbance at $420 \mathrm{~nm}$ of the different musts obtained during grape drying. 


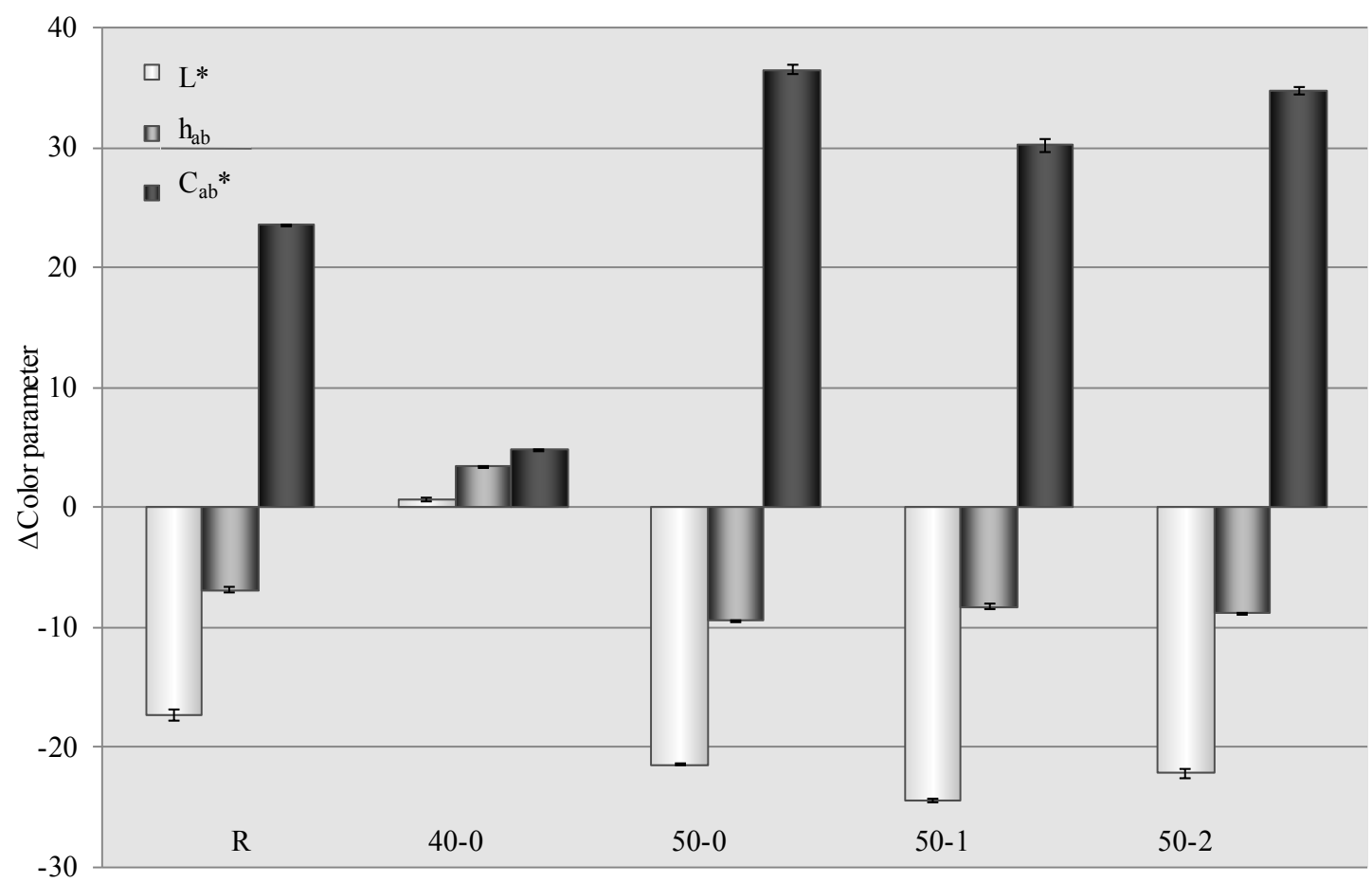

FIGURE 2

Variation of lightness $\left(\mathrm{L}^{*}\right)$ and the angular coordinates in the CIELAB space (hab and $\mathrm{C}^{*} \mathrm{ab}$ ) for musts obtained during grape drying.

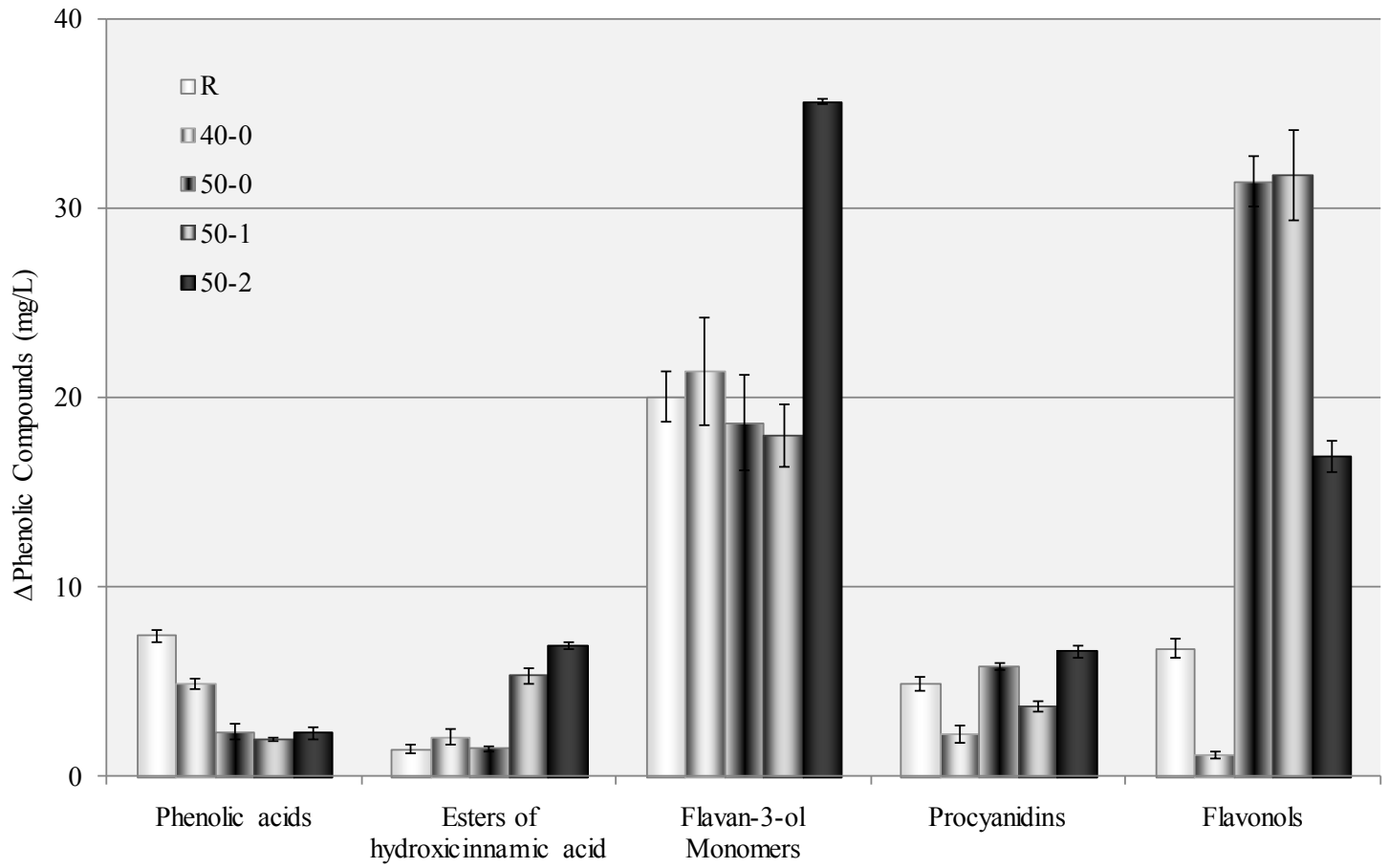

FIGURE 3

Variation of concentration of phenolic compounds $(\mathrm{mg} / \mathrm{L}$ ) for musts obtained during grape drying.

induced by polyphenol oxidases or peroxidases (Macheix et al., 1991) and thus have their concentrations reduced. Some flavan-3-ol derivatives can also be hydrolysed to phenolic compounds of lower molecular weights (Timberlake \& Bridle, 1976; Haslam, 1980; Dallas et al., 1995; Dallas et al., 2003) and thus increase phenol contents. Therefore, changes in these compounds during grape-drying are very often more than the outcome of a mere balance of gains and losses.

The contents of phenolic acids increased to a greater extent in the case of traditional sun-drying (R) versus chamber-drying at $40^{\circ} \mathrm{C}$ in the absence of dipping (40-0), 
whereas the similar increases were observed in the case of the three chamber-drying runs at $50^{\circ} \mathrm{C}$ with and without dipped grapes. Hydroxycinnamic esters increased most in the must from grapes dried at $50^{\circ} \mathrm{C}$ in the chamber after dipping in an alkaline emulsion of ethyl oleate (50-2), followed by the must from grapes dipped in olive oil (50-1). All other musts exhibited a smaller increase than expected as result of the effect of moisture evaporation from the grapes, which suggests a reduction in their concentrations due to their involvement in some of the above-described reactions. The contents in flavan-3-ol monomers increased very markedly with chamber-drying at $50^{\circ} \mathrm{C}$ of grapes dipped in an alkaline emulsion of ethyl oleate (50-2) relative to increases observed with all other drying processes. This may have resulted from the process favoring the hydrolysis of high-molecular weight compounds (Timberlake and Bridle, 1976; Haslam, 1980; Dallas et al., 1995). Procyanidins increased with sun-drying (R) and with chamber-drying at $50^{\circ} \mathrm{C}$ of untreated grapes (500 ) and grapes dipped in an alkaline emulsion of ethyl oleate (50-2). It should be noted that the procyanidin concentration in the must from grapes dried at $50^{\circ} \mathrm{C}$ following dipping in an olive oil-potassium carbonate emulsion (50-1) increased very slightly, possibly because the emulsion contained a chemical agent potentially facilitating the degradation of procyanidins. Flavonols increased similarly in the must from untreated grapes dried at $50^{\circ} \mathrm{C}(50-0)$ and in that from grapes
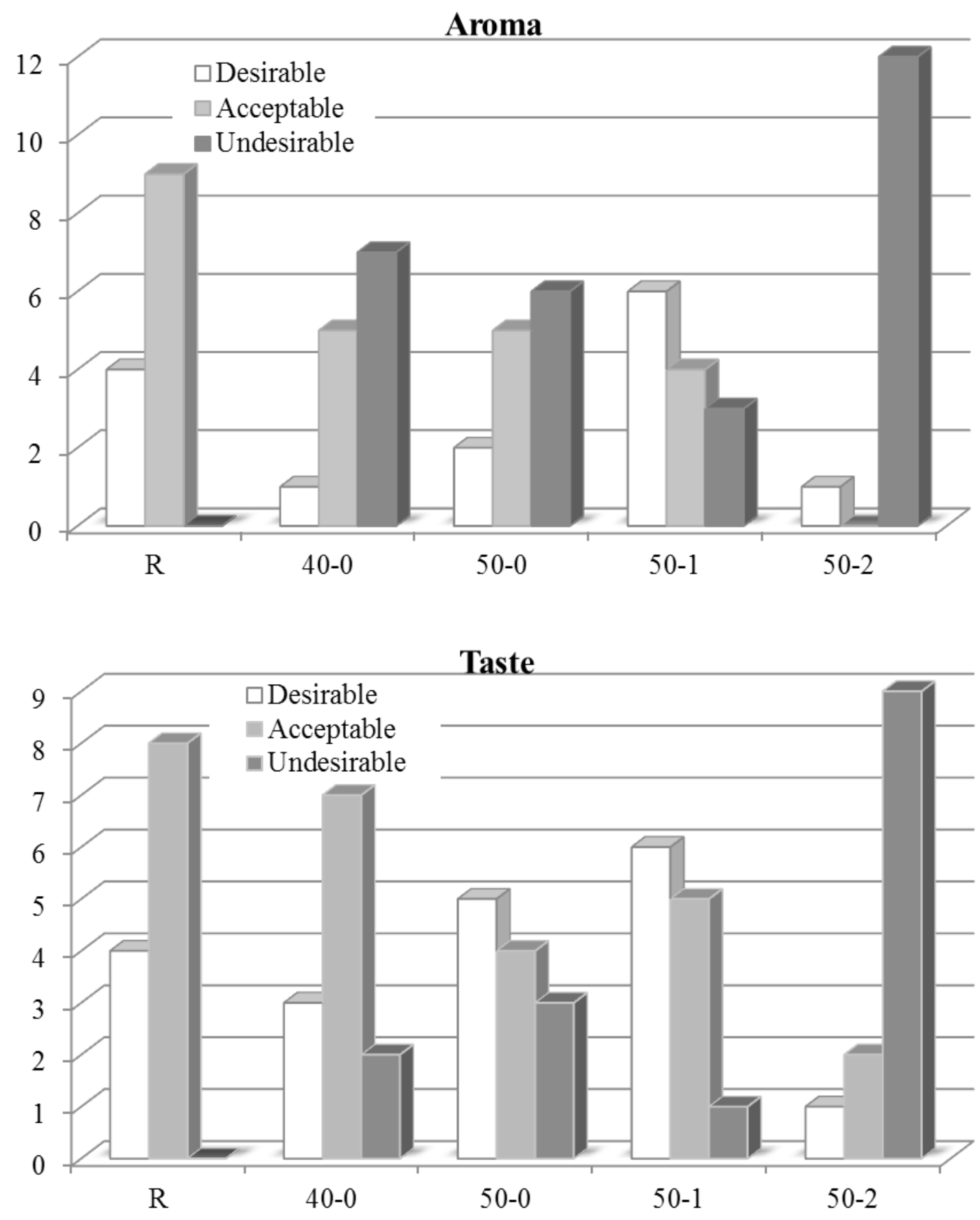

FIGURE 4

Frequency of response for each quality grade used to assess must aroma and flavour from dried grapes. 
treated with the olive oil-potassium carbonate emulsion (50-1).

The sensory characteristics of the different musts obtained from chamber-dried grapes were assessed by two tasting panels. The first was a blind test where the musts were assessed for olfactory and gustatory properties. The test was conducted by 15 tasters using undesirable, acceptable and desirable as ratings. The assessment of the two tasters rating the must from sun-dried grapes as undesirable was rejected. Figure 4 shows the frequency of each quality grade used to assess must aroma and flavor. Based on the results, the must with the most desired aroma was that from grapes dipped in an olive oil-potassium carbonate emulsion and dried at $50^{\circ} \mathrm{C}$ in the chamber (50-1), which was rated undesirable by only $23.1 \%$ of the tasters. The least desired must was that from grapes dried at the same temperature in the chamber, but previously dipped in an alkaline emulsion of ethyl oleate (50-2), which was rated undesirable by $92.3 \%$ of the tasters. All musts were rated acceptable with regards to flavor, with the exception of the must from grapes dried at $50^{\circ} \mathrm{C}$ after dipping in an alkaline emulsion of ethyl oleate (50-2) which was rated undesirable by $75 \%$ of the tasters. All others were rated acceptable or even desirable by at least $75 \%$ of the tasters.

A second test involved assessing must color on a similar scale as aroma and flavor (undesirable, acceptable and desirable). As in the previous test, the ratings of the tasters deeming the reference must undesirable (6 in all), were excluded. The frequency of each quality grade is shown in Fig. 5. The best musts were those from grapes dried at $50^{\circ} \mathrm{C}$ and dipped in an olive oil-potassium carbonate emulsion (50-1) and from similarly dried grapes dipped in an alkaline solution of ethyl oleate (50-2), because these were less often rated as undesirable. These musts were those exhibiting lowest lightness and highest absorbance at $420 \mathrm{~nm}$ (i.e. the darkest, brownest musts). Therefore, the tasters, in the role of consumers, judged the must from grapes dried at $50^{\circ} \mathrm{C}$ in a chamber after dipping in an olive oil-potassium carbonate emulsion (50-1) to have the best aroma, flavor and color.

These results were corroborated by two other expert tasters (winemaking specialists). Consistent with the ratings of the previous tasters, their assessments confirmed that the best must in terms of aroma, flavor and color was obtained from grapes dried at $50^{\circ} \mathrm{C}$ in the chamber after dipping in an olive oil-potassium carbonate solution (50-1), followed by must from un-dipped grapes chamber-dried at the same temperature (50-0).

In summary, drying Pedro Ximenez grapes at a controlled temperature in a chamber has advantages over the traditional sun-drying process. The chamber-drying process enables the selection of more ripened grapes to be used irrespective of the particular climatic conditions of the year, which have a strong impact on sun-dried grapes. As a result, the drying time required to obtain raisins of similar sugar content can be substantially shortened. The chamber-drying process also results in better grape health as it prevents toxinproducing fungi growth (Serratosa et al., 2010). In addition, chamber-drying of grapes at $50^{\circ} \mathrm{C}$ provides must with very similar characteristics to that from sun-dried grapes except for a slightly lower lightness and chroma. The must from grapes dried at $50^{\circ} \mathrm{C}$ in a chamber following dipping in an alkaline emulsion of ethyl oleate $\left(2.5 \% \mathrm{~K}_{2} \mathrm{CO}_{3}+2 \%\right.$ ethyl oleate) was rated as the least desirable in the sensory tests. Therefore, although this treatment expedited grape-drying to the greatest extent, its effected on aroma, flavor and color is undesirable to customers. The must from grapes dried at

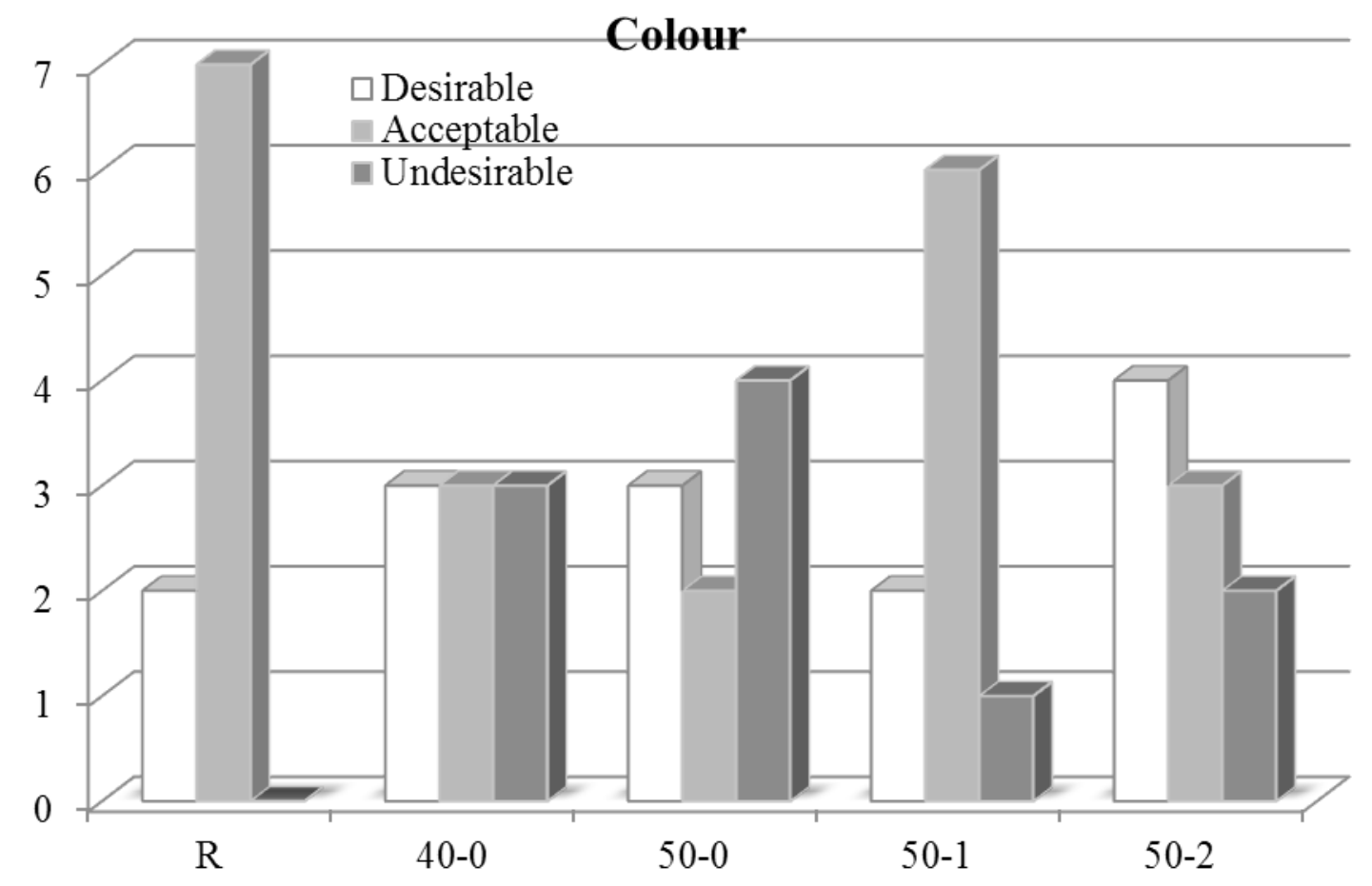

FIGURE 5

Frequency of response for each quality grade used to assess must color from dried grapes. 
$40^{\circ} \mathrm{C}$ in the chamber was rated undesirable on account of its light color. Finally, the musts from grapes dried at $50^{\circ} \mathrm{C}$ in the chamber following dipping in an olive oil-potassium carbonate emulsion or with no dipping received the best ratings. However, the dipping treatment failed to expedite drying relative to the use of un-dipped grapes. Thus, it provides no benefit to the chamber-drying treatment. Future research on other grape varieties than Pedro Ximenez is necessary to elaborate on the effect of chamber drying of grapes at this or other temperatures on sweet wines .

\section{LITERATURE CITED}

Azzouz, S., Guizani, A., Jomaa, W. \& Belghith, A., 2002. Moisture diffusivity and drying kinetic equation of convective drying of grapes. J. Food Engin. 55, 323-330.

C.I.E., 2004. Colourimetry. Publication of the International Commission on Illumination, $3^{\text {th }}$ edition, Vienna, Austria.

Cheynier, V., Basire, N. \& Rigaud, J., 1989. Mechanism of transcaffeoyltartaric acid and catechin oxidation in model solutions containing grape polyphenoloxidase. J. Agric. Food Chem. 37, 1069-1071.

Dallas, C., Ricardo-Da-Silva, J.M. \& Laureano, O., 1995. Degradation of oligomeric procyanidins and anthocyanins in a Tinta Roriz red wine during maturation. Vitis 34, 51-56.

Dallas, C., Hipolito-Reis, P., Ricardo-Da-Silva, J.M. \& Laureano, O., 2003. Influence of acetaldehyde, $\mathrm{pH}$, and temperature on transformation of procyanidins in model wine solutions. Am. J. Enol.Vitic. 54, 119-124.

Doymaz, I. \& Pala, M., 2002. The effects of dipping pretreatments on airdrying rates of the seedless grapes. J. Food Engin. 52, 413-417.

Grncarevic, M. \& Hawker, J.S., 1971. Browning of sultana grapes berries during drying. J. Sci. Food and Agric. 22, 270-272.

Haslam, E., 1980. In vino veritas: oligomeric procyanidins and the ageing of red wines. Phytochem. 19, 2577-2582.

Jaworski, A. \& Lee, C.Y., 1987. Fractionation and HPLC determination of grape phenolics. J. Agric. Food Chem. 35, 257-259.

Karathanos, V.T. \& Belessiotis, V.G., 1997. Sun and artificial air drying kinetic of some agricultural products. J. Food Engin. 31, 31-35.

Lingnert, H. \& Hall, G., 1986. Formation of antioxidative Maillard reaction products during food processing. In: Fujimaki, M., Namiki, M. \& Kato, E. (eds). Amino-carbonyl reactions in food and biological systems. Elsevier, Tokyo, Japan. pp. 273-279.

Macheix, J.J., Sapis, J.C. \& Fleuriet, A., 1991. Phenolic compounds and polyphenoloxidase in relation to browning in grapes and wines. Crit. Rev. Food Sci. Nutrit. 30, 441-486.
Mahmutoglu, T, Emir, F \& Saygi, Y.B., 1996. Sun/Solar drying of differently treated grapes and stability of dried grapes. J. Food Engin. 29, 289-300.

Morales, F.J. \& Jimenez-Perez, S., 2001. Free radical scavenging capacity of Maillard reaction products as related to colour and fluorescence. Food Chem. 72, 119-125.

Oszmianski, J., Ramos, T. \& Bourzeix, M., 1988. Fractionation of phenolics compounds in red wines. Am. J. Enol. Vitic. 39, 259-262.

Pangavhane, D.R., Sawhney, R.L. \& Sarsavadia, P.N., 1999. Effect of various dipping pretreatment on drying kinetics of Thompson seedless grapes. J. Food Engin. 39, 211-216.

Pangavhane, D.R. \& Sawhney, R.L., 2002. Review of research and development work on solar dryers for grape drying. Energy Conversion and Management 43, 45-61.

Radler, F., 1964. The prevention of browning during drying by the cold dipping treatment of sultana grapes. J. Sci. Food Agric. 15, 684-689.

Ramshaw, E.H. \& Hardy, P. J., 1969. Volatile compounds in dried grapes. J. Sci. Food Agric. 20, 619-621.

Raouzeos, G.S. \& Saravacos, G.D., 1986. Solar drying of raising. Drying Technol. 4 (4), 633-649.

Riva, M., Peri, C. \& Lovino, R., 1986. Effects of pretreatments on kinetics of grapes drying. In: Le Maguer \& Jelen (eds). Food Engineering and Process Applications. Transport Phenomena, vol 1. Elsevier Applied Science, London. pp. 461-472.

Saravacos, G.D., Marousis, S.N. \& Raouzeous, G.S., 1988. Effect of ethyl oleate on the rate of air-drying of foods. J. Food Engin. 7, 263-270.

Saravacos, G.D., Tsiourvas, D.A. \& Tsami, E., 1986. Effect of temperature on the water adsorption isotherms of sultana raisins. J. Food Sci. 51, 381387 .

Serratosa, M.P., Lopez-Toledano, A., Merida, J. \& Medina, M., 2008a Changes in color and phenolic compounds during the raisining of grape cv. Pedro Ximenez. J. Agric. Food Chem. 56, 2810-2816.

Serratosa, M.P., Lopez-Toledano, A., Medina, M. \& Merida, J., 2008b. Drying of Pedro Ximenez grapes in chamber at controlled temperature and with dipping pretreatments. Changes in the color fraction. J. Agric. Food Chem. 56, 10739-10746.

Serratosa, M.P., Lopez-Toledano, A., Millan, C.; Medina, M. \& Merida, J., 2010. Changes of ochratoxin A in grapes inoculated with Aspergillus carbonarius and subjected to chamber-drying under controlled conditions. J. Agric. Food Chem. 58, 11907-11912.

Timberlake, C.F. \& Bridle, P., 1976. Interactions between anthocyanins, phenolic compounds and acetaldehyde and their significance in red wines. Am. J. Enol. Vitic. 27, 97-105. 